\title{
Promoting Chinese Cultural Heritage Tourism in Sri Lanka during Post-COVID19 Revival Phase: Viewpoint
}

\author{
Samarathunga, WHMS \\ Department of Tourism \& Hospitality Management, Faculty of Management Studies, Rajarata University of Sri \\ Lanka, Mihintale, 50300, Sri Lanka \\ manoj.susl@gmail.com
}

\begin{abstract}
The Chinese outbound tourists have received the spotlight of many destinations around the world. Therefore, the main aim of this article is to discuss the Chinese cultural heritage tourism potential in Sri Lanka with the purpose of attracting Chinese tourists to Sri Lanka during the post-COVID19 tourism revival phase. The study critically evaluates the previous literature on Chinese outbound tourism, heritage tourism, and Chinese cultural heritage in Sri Lanka. The study follows an interpretivism research approach. The study identified the potential of attracting Chinese outbound tourists to Sri Lanka after developing Chinese Cultural Heritage in Sri Lanka as a niche tourism product. The study further examined the resilience of the Chinese outbound market against the COVID19 pandemic and makes recommendations to attract Chinese tourists to Sri Lanka during the post-COVID19 revival phase. This viewpoint paper provides practical implications to Sri Lanka tourism policy makers and practitioners on how to attract the Chinese outbound tourists, which has not been systematically studied before.
\end{abstract}

Keywords: Post-COVID19 tourism, Chinese outbound tourism, cultural heritage tourism, tourism recovery and resilience and post-pandemic tourism 


\section{Introduction}

People have been travelling since the great medieval era for different purposes. As of now, tourism is being anticipated and experienced in different ways than previously. Visits to cultural and heritage spaces are considered as one of the main components of today's travels (Kerstetteret al., 2001). Cultural and heritage tourism can be viewed as being a type of special interest tourism (Nuryanti, 1996). In a narrow sense, cultural and heritage tourism is, special interest holidays (vacations) essentially motivated by cultural interests, such as trips and visits to historical sites and monuments, museums and galleries, artistic performances and festivals, as well as lifestyles of communities. In a broad sense, it includes activities with a cultural content as parts of trips and visits with a combination of pursuits (Medlik, 2003; Hewison, 1987).

Heritage is a complex notion based on historical events and experiences as well as artefacts. However, meanings and understandings are shaped by contemporary circumstances and thoughts about the future alongside personal and group perspectives (Nuryanti, 1996; Ashworthet al., 2000). Built heritage is very often recognized as one form of cultural heritage. As stated in the "United Nations World Heritage Convention Concerning Protection of the World Cultural and Natural Heritage" there are three main components of inbuilt heritage (Hewison, 1989; Ross, 1991; Samarathunga, 2019). First, monuments: architectural works; works of monumental sculpture and painting; elements or structures of an archaeological nature; inscriptions, caves, and dwellings; and combinations of features that are of outstanding universal value from the point of view of history, art, or science. Second, groups of buildings: groups of separate or connected buildings that, because of their architecture, their homogeneity, or their place in the landscape, are of outstanding universal value from the point of view of history, art, and science. Third, sites: works of man or combined works of nature and man, and areas including archaeological sites that are of outstanding universal value from the historical, aesthetic, ethnological, or anthropological points of view (Nuryanti, 1996). 
Conserved heritage can perform useful social and cultural functions by inculcating national and civic pride and feelings of connections (Torre, 2002). In developing countries, the development of heritage tourism involves not only reconstructing the past; it is also part of restructuring the economies (Nuryanti, 1996). Heritage's development and marketing as a visitor attraction demonstrates a capacity to earn income directly and indirectly (Rypkema 2008; Timothy and Nyaupane 2009; Henderson, 2012). Further, it contributes to the development of economies (Bellini et al., 2007; Henderson, 2012), improve the lives of residents (Mathieson and Wall 1982), and has the potential to be a sustainable development tool by helping to make cities more attractive destinations in which to stay, work, visit and invest (Hutton, 2003). Consequently, it is vital that cultural sites are promoted with a proper plan to earn the maximum benefits to a country.

Cultural heritages also face challenges in their existence. Much of the danger to built heritage sites arguably results from destruction for tourism development; crowding and congestion, or from the inappropriate behaviour of visitors, such as touching delicate surfaces, littering and vandalism (Moscardo, 1996). Showcasing of culture and history can create antagonisms, especially if it is left completely in the hands of marketers to decide what to represent (Teo and Yeoh, 1997). Thus, it is important to identify, document, and conserve the cultural heritage at a destination before the profit-seeking sectors get involved with it. The authentic heritage tourist sites and authentic presentation to the tourists will always create a constant visitor demand (Yi et al., 2017). Since the cultural tourists spend a relatively short time at built attractions, they tend to demand "show and know" the past, rather than to be amazed or entertained(McIntosh and Prentice, 1999). This is reflected in recent trends among global travellers who seek novelty through a return to traditional social values; whose new tastes and styles refer back to the past; and whose demands have become more specialized (Nuryanthi, 1996). Therefore, it is important to plan the cultural sites in such a way that busy tourists can experience the cultural sites in the shortest period. 
Sri Lanka is an island destination in the Indian Ocean, which is famous as a paradise for tourism. The end of the three decades-long separatist war opened up new avenues for Sri Lanka tourism and it is on its way to emerging as a successful tourism destination despite of many post-war empirical glitches (Liyanage \& Jayawardena, 2013; Dissanayake \& Samarathunga, 2020). Although proper planning is deemed necessary to position Sri Lanka as a pristine destination (Lokuhetty, et al,. 2013) the industry questions the effectiveness of current promotional plans. Therefore, it is vital to set realistic tourism plans to harvest the maximum benefits to Sri Lanka tourism (Fernando and Jayawardena, 2013; Samarathunga, et.al, 2020). In this context, looking at the growing Chinese outbound market seems very effective during the post-COVID19 revival phase. Therefore, this viewpoint paper primarily focuses on how to promote Chinese culture and heritage tourism potentials in Sri Lanka during the post-COVID19 tourism revival phase. Further, motivations of potential Chinese visitors to Chinese cultural heritage sites in Sri Lanka by emphasizing the relationships between the individuals and the sites are investigated. Thus, it is important to identify the nature of the Chinese outbound market and their preferences as well.

\section{Chinese Outbound Tourism Market}

An old Chinese saying is, 'He who travels far knows much' (author anonymous). The Chinese population is growing in affluence, with outbound travel continuing to climb as more people can afford the luxury of tourism experiences (WTO, 2003). The rapid development of the Chinese economy has provided motivation for the development of sustainable outbound tourism (China Tourism Academy, 2010). China is the number one international tourism source market in the world in terms of border-crossings and spending (Arlt, 2013a; China Tourism Academy, 2010). 90\% of all affluent Chinese have already visited Europe. Almost all affluent Chinese have been outside Mainland China at least once (Arlt, 2013a). Over 70\% of Chinese tourists travel abroad at least once a year. Active outbound tourists who go abroad several times annually account for $36.97 \%$ of the total (World Tourism Cities 
Federation, 2014). Chinese in the middle and top incomes are already starting to consider travel a 'birthright' (World Travel and Tourism Council, 2020) and there have been an increasing number of Chinese taking outbound trips (China National Tourism Administration, 2007). In 2020 one out of seven of all international border crossings will start from Mainland China, conducted by approximately $9 \%$ of Mainland Chinese citizens (Arlt, 2013b). The significance of the Chinese outbound market segment has been identified as a lucrative market segment by most destinations and regions. Thus, most of the destinations are now maintaining convenient visa policies for Chinese citizens and diversified promotion activities (China Tourism Academy, 2010).

Until now, tourists from China have visited well-known "must-see" destinations and attractions. However, the modern Chinese outbound tourists are leaving the "beaten track"(Arlt, 2013a). Arlt (2013a) further explains that, the "Second Wave" travellers move from "money-rich and time-poor" to "money and experience rich and timepoor", looking for new kicks and lifestyle affirmation, new destinations, and authentic activities, clean nature, culture and stories to tell. This has created lucrative opportunities to developing countries to grab this mammoth market. China Tourism Academy (2010) also confirms that outbound tourists from North China mainly travel to surrounding countries and regions. The Second Wave Chinese travellers can be attracted to new places, new activities, new times of the year, bringing not only more, but a different kind of business. In order to get the advantage of this trend, it is important to give the right kind of reasons to come that include novelty, exclusivity, intensity, connection to China, endorsement by a celebrity, quality labels, and social media hype. If they are given the right story to tell and the feeling of being more welcomed as Second Wave Chinese travellers than any other kind of customer the arrival of Chinese tourists will be unstoppable (Arlt, 2013a).

The potential of attracting second-wave travellers to cultural and heritage sites is more promising. The desire to see well-known attractions stand out as the major motivation for Chinese travelling overseas. Chinese tourists appear to have high 
regard for monuments that have a historical, cultural or contemporary significance. They are some of the key destination attributes that are likely to be attractive to outbound Chinese tourists (Zhou, King, and Turner, 1998; Kim et al., 2005). This is further confirmed by the 2014 Market Research Report on Chinese Outbound Tourists (City) Consumption. According to this market report by World Tourism Cities Federation (WTCF), 87\% of the Chinese outbound tourists prefer sightseeing as the primary purpose of travel followed by the availability of unique culture with $68 \%$ and long history $53 \%$. The same report evident that Historical sites as the second most chosen sites with $73 \%$ preference closely preceded by Natural Scenery with $87 \%$ preference for Chinese tourists when they tour in outbound cities. Further to that, the vast majority of cultural visitors indicated that visits to cultural attractions on holidays were a reflection of cultural visits made in their home country or region (Tse, 2013). Walsh (1992) argues that heritage tourism is closely linked with the rise of "the new middle class" or the "service class". However, it is not simply the consumption of heritage that is determined by the rise of the new middle class, but also the production of heritage. The potential that exists in Sri Lanka to attract this segment is explained in the succeeding section.

\section{Sri Lanka Tourism With Chinese Cultural Heritage}

From medieval times, because of its location in the Indian Ocean, Sri Lanka has attracted merchants, marine explorers, and invaders. In addition, the treasure of Buddhism, the bracing climate, and the hospitality of the natives, all paved the way to its reputation. While mercantile quests first brought the Chinese and the Sri Lankans together, the interest in Buddhism created a healthy relationship between the two countries from the third century A.D. The Bhikku Fa-Hien (3-4 A. D.) stands out among all these travellers as he had documented all his associations with Sri Lanka. According to the inscriptions, the Fa-Hien Bhikku travelled along the Silk Road to India and from there by boat to Sri Lanka in between 399 - 412 AD in search of Buddhist scripts. He spent two fruitful years in Sri Lanka and boarded a merchant ship to travel back to China. Sri Lankan evidence further suggests that he 
stayed in Abhayagiriya (a key ancient Dhamma School in Sri Lanka) with 5000 Buddhist monks studying Buddhism, Phahiyangala (a rock cave in the Western province of the country) (Weerasinghe, 1995; Saunders, 1996; Kularathna, 2015). The story of Admiral Zheng He / Cheng Ho is both true and epic. His sea voyages explored the ancient world and brought them together. Although at certain instances he used his military powers, i.e. the ruler of Sri Lanka refused to recognize the emperor Ming and was taken to China as a prisoner, while a similar fate befell two rulers in Sumatra, and in most other instances the voyages have been diplomatic (Lunde, 2005). Zheng He's treasure ships were 450 feet long and suggest that there were 200-300 men on the ships. Zheng visited Sri Lanka 6 times out of his 7 voyages to around 30 countries, during the Chinese Ming Dynasty (Church, 2005; Sri Lanka Tourism Promotion Bureau, 2012). "Zheng He is a hero in China but sadly, his visits to Sri Lanka are not very much known in China", reported by the Xinhua News Agency in 2017. One of the strong pieces of evidence about the arrival of Zheng He to Sri Lanka is mentioned in Galle Trilingual Inscription (erected in 1411) which is being exhibited in Colombo National Museum. This evidence strongly suggests that he visited Sri Lanka 100 years, 233 years, and 397 years before the Portuguese, Dutch and British. Even the ancient diplomatic records of Rome confirm Chinese traders' visits to Mantota(present: Mannar) harbour in 52 BC (Sri Lanka Tourism Promotion Bureau, 2012). Further to, the Sri Lankan ancient records of Mahawamsa also affirms Sri Lanka and China diplomatic and trade relationships from the $1^{\text {st }}$ century BC (Weerasinghe, 1995). In addition, there is plenty of evidence in Sri Lankan literature highlighting the hundred years of Sri Lanka and China relationships around the country including the trade missions, religious missions, and diplomatic missions. It can be further argued that all this evidence are found along with the sea-based Silk route, which once connected the Eastern and Western worlds.

\section{One Belt One Road And Sri Lanka}

Chinese One Belt One Road (OBOR) is one of the key development projects that the world has seen in recent decades. Under the visionary leadership of President Xi 
Jinping, the OBPR was first proposed in 2013 to demarcate the one hundred year's celebrations of the establishment of the Chinese Communist Party (CCP). The OBOR project follows the ancient silk route, both land and maritime, that brought East and West together many centuries ago. Following the guiding starts set by their ancestors, most of the OBOR projects are now taking place along the ancient silk route, which are aimed at accelerating the development of China by promoting Chinese investments in countries that fall under the purview of OBOR project. Morgan Stanley, a renowned global investment bank estimates that by 2027 China's overall expenses over the life of the OBOR could reach $\$ 1.2-1.3$ trillion with sixty countries partnering with the project (Morgan Stanley, 2018). Although there are many benefits of OBOR projects to the host country, many scholars have pointed out the demerit of it. Ownership of economically valuable assets in other countries, spying over countries, influence over political matters and sovereignty, strict credit terms and conditions, expanding Chinese military power are a few of them (Alguacil, Cuadros and Orts, 2011; Fasslabend, 2015; Kleven, 2015; Aoyama, 2016; Ferdinand, 2016; Liu et al., 2017; Var and Po, 2017; Jetin, 2018).

Sri Lanka is located in the heart of the ancient maritime silk route that has connections with the ancient silk route since the $13^{\text {th }}$ century A.D. Sri Lanka started diplomatic relationships with China after Admiral Zheng-Ho (Zheng-he) visited Sri Lanka in the $13^{\text {th }}$ and $14^{\text {th }}$ century A.D. (Dewaraja, 2006). Reflecting the strength of the relationship between the Sri Lankan Government and the Chinese Government, there are many Chinese investments projects in Sri Lanka. Some of the key OBOR projects in Sri Lanka are presented in Table 1. According to Table 1, the direct value of OBOR loans and investments in Sri Lanka is well over US\$ 7.5 billion. Therefore, it is important to have stable socio-political and economic conditions in Sri Lanka to achieve the objectives of both Sri Lanka and China. 


\begin{tabular}{|l|l|c|c|}
\hline$\#$ & Name of the project & $\begin{array}{c}\text { Loan / } \\
\text { Investment }\end{array}$ & $\begin{array}{c}\text { Amount } \\
\text { (US\$ millions) }\end{array}$ \\
\hline 1 & Southern Expressway & Loan & 1,545 \\
\hline 2 & Norochcholai Coal Power Plant & Loan & 1,346 \\
\hline 3 & $\begin{array}{l}\text { Hambantota Port Development } \\
\text { Project }\end{array}$ & Loan & 1,335 \\
\hline 4 & Colombo Port City & Investment & 1,300 \\
\hline 5 & CICT Colombo Terminal & Investment & 500 \\
\hline 6 & Rehabilitation of Northern Roads & Loan & 2402 \\
\hline 7 & Colombo-Katunayake Expressway & Loan & 292 \\
\hline 8 & $\begin{array}{l}\text { HambantotalMattala International } \\
\text { Airport (Phase I \& II) }\end{array}$ & Loan & 214 \\
\hline 9 & $\begin{array}{l}\text { Moragahakanda-Kalu Ganga } \\
\text { Development Project }\end{array}$ & Loan & 278 \\
\hline 10 & Extension of Southern Railway & Loan & 104 \\
\hline 11 & Colombo Lotus Tower & Loan & 79 \\
\hline 12 & Greater Kurunegala Water Supply & Loan & \\
\hline
\end{tabular}

Table 1: Chinese OBOR investments and loans in Sri Lanka

Source: Bhatia et al., (2016), Wignaraja et al. (2020)

The completed and ongoing OBOR projects in Sri Lanka attract a large number of Chinese employees, businessmen, contractors, and diplomats at various levels. This upward trend could be seen since 2010 when Sri Lanka ended terrorism and started the development battle.

\section{Developing Sri Lanka As A Chinese Cultural Tourism Destination}

Heritage requires more than documentation and preservation. Its heritage and archaeological value should be conveyed to the visitors (Nuryanti, 1996). However, converting cultural items into tourism products does not have only detrimental effects but has both positive and negative implications for the local and tourist communities (Chang, 1997). Thus, it is important that introduction of proper tourism concepts to the Chinese culture and heritage sites in Sri Lanka. 
Sri Lanka tourism enjoyed the highest number of Chinese tourists' arrivals during 2018 and 2019. Sri Lanka's tourism industry has acknowledged China as an important emerging market. The number of Chinese arrivals to Sri Lanka has increased at an increasing rate during the last decade (Sri Lanka Tourism Development Authority, 2016). Although the literature related to Chinese inbound tourists is very low, a few articles and books are published in Sri Lanka. Silva and Lasanthi (2014) suggested that Sri Lanka needs to diversify its tourism attractions to attract more Chinese tourists. The recent report entitled 'Survey of Departing Foreign Tourists from Sri Lanka' (Sri Lanka Tourism Development Authority, 2016), reports that Chinese tourists expect Chinese culture in Sri Lanka: people to speak the Chinese language, their Union Bank payments, Chinese food, to visit China Town and places of importance to Chinese people. The purposes of the Chinese tourists to visit Sri Lanka are for recreation, business, religion and culture according to the Survey Report. However, Silva and Lasanthi (2014) conclude that although Sri Lanka is known to the Chinese people, the lack of information about Chinese culture and heritage values stops people to travel to Sri Lanka. This is mainly because Sri Lanka is more focused on physical infrastructural development, not product development when it comes to tourism planning (Samaranayakeet al, 2013).

\section{Covid19 And Chinese Outbound Tourism In Sri Lanka}

COVID19 has imposed an irreversible impact on world tourism (Samarathunga, 2020; Samarathunga and Weerathunga, 2020; Weerathunga and Samarathunga, 2020). China has been very much successful in controlling the spread of the deadly virus. Since 2011, Chinese tourists have been visiting Sri Lanka at an increasing rate who also spend handsomely at the hotels, tourist shops, and for other tourism services. China has been the largest source market in the world since 2012. In 2018, there were around 150 million outbound trips from China, and Chinese tourists spent over US \$277 billion in their travels abroad (United Nations World Tourism Organization, 2019). On the other hand, in 2018 Sri Lanka received only 265,965 
(167,863 in 2019) number of Chinese tourists ( $0.1 \%$ of the total outbound traffic). According to Travel China Guide Vietnam, Thailand, Japan, Indonesia, Singapore, Malaysia, Hong Kong, Philippines, Cambodia, and Macau have been the top China outbound destinations (Pacific Asia Travel Association, 2020).In comparative terms, the effectiveness of the Sri Lankan pandemic controlling mechanism is equal or better than most of the above countries (Weerathunga and Samarathunga, 2020). On the contrary, some European and American leaders have made controversial statements regarding the COVID19 to the disappointment of China. Additionally, the West has developed stereotype mentalities towards Chinese people which will affect negatively Chinese travelling in the West.

This will open up new avenues for Sri Lanka to attract more high spending Chinese tourists in the year to come provided we do our homework well. It is also important to highlight the favourable economic and political ties that both countries are sharing, which will ease any future bottleneck. The latest study report by Pacific Asia Travel Association (PATA) along with CCT and IVY Alliance highlights the post-COVID19 travel behaviour of Chinese tourists. According to the reports Japan $(18 \%)$ and Thailand (14\%) will remain as the most preferred travel destinations among the Chinese tourist, followed by European countries (14\%), and Maldives, Singapore, New Zealand, Australia, South Korea, Sri Lanka and Malaysia (Pacific Asia Travel Association, 2020).

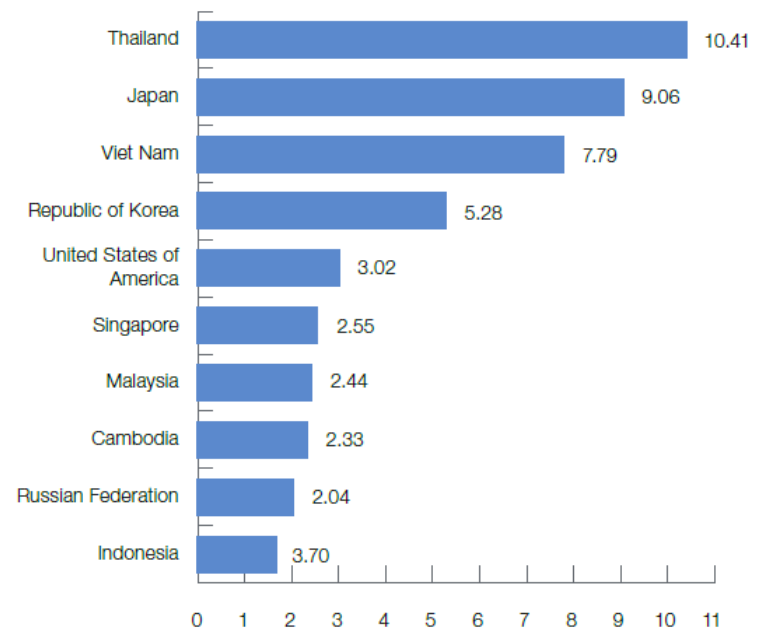

Figure 1: Chinese outbound travels to top 10 destinations in 2018

Source: UNWTO (2019) 
Continuous promotions in other conventional tourism markets that include the UK, Germany, Australia, France, United States, and Canada should not be forgotten because in near future the world will discover long waiting for curative and preventive vaccines to combat COVID19. Small elite clusters from those countries will continue to make international travels immediately after lifting the travel bans and Sri Lanka will get their limelight as a "Safe" destination to travel. Therefore, it is our responsibility to handle the existing and emerging markets in efficient ways to get the maximum benefits under the new circumstances.

\section{Conclusion}

Although promoting foreign cultures as a part of tourist attractions at the destination areas has not been a popular researchable area. There is much evidence proving the fact that foreign tourists prefer to see their culture in other countries. For example, Kampung Baru in Kuala Lumpur has been a very popular destination to visit among British tourists due to its British colonial remains (Ar, 2009; Henderson, 2012). Henderson (2000) further points out that Manila's Spanish colonial architecture and buildings which date back to the $15^{\text {th }}$ century are the key attractions to visit among Spanish tourists. Similar to that, in Singapore, Chinatown Historic District is the most popular destination among tourists in 1998. Another popular destination among the Chinese tourists in Singapore is Tiger Balm Gardens (Haw Par Villa) which depicts scenes from Chinese mythology, folklore, legends, history, and illustrations of various aspects of Confucianism (Teo and Yeoh, 1997). Therefore, following the best practices, the possibility of attracting Chinese outbound tourists to Sri Lanka seems relatively easy than attracting long-haul tourists.

There is no doubt that the future tourism industry of most countries will fall in the hands of the Chinese outbound tourists. This largest, fastest-growing, and elite market will also decide the success or failure of most of the destinations in the future. The present viewpoint paper of the Chinese outbound market gestures that the Chinese travellers tend to be heterogeneous rather than homogeneous. Thus, there will be an increased demand for niche tourism concepts including visiting 
ancient cultural heritage sites that has a relationship to modern Chinese travellers. Cultural and heritage tourism is not only viewed as a concept that increases the awareness of the tourists about history, archaeology, or anthropology but also it has been found out as an important economic driver that converts stagnated economies into booming economies. Therefore, post COVID19 tourism plans in Sri Lanka should be more sensitive to the ever-growing Chinese outbound market.

\section{Recommendations}

The study put forward the following implications to attract more Chinese tourists to Sri Lanka:

1. To identify the Chinese culture and heritage sites in Sri Lanka through proper scientific investigations and conserve them, and convert them into tourism products;

2. Promote Mandarin language education in Sri Lanka;

3. Empowering the tourist service personnel with Chinese language competency;

4. Promote online check-in's and check-outs at the hotels to save time;

5. Introducing We-chat and Ali-pay payment methods to Chinese tourists to pay in $\mathrm{RMB}$;

6. Sri Lanka to have more direct flights from Chinese tourist generating areas;

7. Promoting alternative tourism including eco-tourism, responsible tourism, community-based tourism, Ayurveda and Yoga, bird watching, agro-tourism, etc. instead of conventional mass tourism;

8. Recommending longer credit facilities to be given to stable tour operators;

9. Encouraging the Chinese tour operators to encourage their credit card companies to offer interest-free instalment payments for travellers on travel plans; 
10. Identifying the shopping behaviour of Chinese tourists and developing shopping tourism;

11. Involve more activities at tourist destinations by means of value addition;

12. Conducting more research on outbound Chinese tourists, trends, and patterns;

13. Preparing the local communities to welcome and host tourists.

14. To restructure the existing tourism promotional campaigns, which can reach the Second Wave of Chinese tourists through Chinese media, internet platforms, and popular mobile Apps.

\section{References}

Ar, A. (2009). Legacies of An Urban Village: Kampung Barn History, Architectural Features and Heritage. PAM CPD Seminar 2009, (pp. 24-32). Kuala Lumpur.

Arlt, W. G. (2013a). The second wave of Chinese outbound tourism. Tourism Planning \& Development, 10(2), 126-133.

Arlt, W.G. (2013b). Who are the new Chinese Tourists and how to attract them? Beijing: China Outbound Tourism Research Institute.

Ashworth, G. J., Graham, B., \&Tunbridge, J. E. (2000). A geography of heritage: power, culture and economy. London: Arnold.

Bellini, E., Gasparino, U., Del Corpo, B., \&Malizia, W. (2007). Impact of cultural tourism upon urban economies: an econometric exercise.Fondazione Eni Enrico Matteiworking Paper Series, No. 85.

Chang, T. C. (1997). Heritage as a tourism commodity: traversing the tourist-local divide. Singapore Journal of Tropical Geography, 18(1), 46-68.

China National Tourism Administration. (2007). ADS first stop in Nielson PATA Travel Mart - Bali. Beijing: China National Tourism Administration. 
China Tourism Academy (CTA). (2010). Annual Report China Outbound Tourism Development 2009/2010. Munich: China Tourism Academy.

Church, S. K. (2005). Zheng He: An investigation into the plausibility of 450-ft treasure ships. Monumentaserica, 53(1), 1-43.

Dissanayake, D.M. M. I., \& Samarathunga, W. H. M. S. (2021). Post-war city to a tourism city: the perspectives of local stakeholders on post-war city tourism development in Jaffna, Sri Lanka. International Journal of Tourism Cities.7(3), 602-621

Fernando, P. and Jayawardena, C. (Chandi) (2013) 'Focusing on realistic tourism targets for post-war Sri Lanka', Worldwide Hospitality and Tourism Themes, 5(5), pp. 495-504. DOI: https://doi.org/10.1108/WHATT-05-2013-0031.

Henderson, J. C. (2000). Attracting tourists to Singapore's Chinatown: A case study in conservation and promotion. Tourism Management, 21(5), 525-534.

Henderson, J. C. (2012). Conserving heritage in South East Asia: Cases from Malaysia, Singapore and the Philippines. Tourism Recreation Research, 37(1), 47-55.

Hewison, R. (1987). The Heritage Industry: Britain in a Climate of decline. London: Methuen.

Hewison, R. (1989). Heritage: an interpretation. Heritage interpretation, 1, 15-23.

Hutton, T. A. (2003). Service industries, globalization, and urban restructuring within the Asia-Pacific: new development trajectories and planning responses. Progress in planning, 61(1), 1-74.

Kerstetter, D. L., Confer, J. J., \&Graefe, A. R. (2001). An exploration of the specialization concept within the context of heritage tourism. Journal of Travel Research, 39(3), 267-274.

Kim, S. S., Guo, Y., \&Agrusa, J. (2005). Preference and positioning analyses of overseas destinations by mainland Chinese outbound pleasure tourists. Journal of travel research, 44(2), 212-220.

Kularathna, S. (2015). Images of Sri Lanka through Bhikku Fa-Hien's Eyes. Chinese Heritage in Sri Lanka (p. 14). Colombo: University of Kelaniya. 
Liyanage, U. and Jayawardena, C. (Chandi) (2013) 'Towards a positioning strategy for tourism in post-war Sri Lanka', Worldwide Hospitality and Tourism Themes, 5(5), pp. 477485. DOI: https://doi.org/10.1108/WHATT-05-2013-0029.

Lokuhetty, A., Jayawardena, C. (Chandi) and Mudadeniya, D. (2013) 'Developing a shared vision for tourism in post-war Sri Lanka', Worldwide Hospitality and Tourism Themes, 5(5), pp. 486-494. DOI: https://doi.org/10.1108/WHATT-05-2013-0030.

Lunde, P. (2005). The Admiral Zheng He. Saudi Aramco World, 45-48.

Mathieson, A., \& Wall, G. (1982). Tourism, economic, physical and social impacts. Longman.

McIntosh, A. J., \& Prentice, R. C. (1999). Affirming authenticity: Consuming cultural heritage. Annals of tourism research, 26(3), 589-612.

Medlik, S. (2003). Dictionary of Travel, Tourism and Hospitality. Burlington: ButterworthHeinemann.

Moscardo, G. (1996). Mindful visitors: Heritage and tourism. Annals of tourism research, 23(2), 376-397.

Nuryanti, W. (1996). Heritage and postmodern tourism. Annals of tourism research, 23(2), 249-260.

Pacific Asia Travel Association. (2020). Survey Report on Chinese Tourists' Travel Intent After the End of COVID-19 Epidemic. Retrieved from https://www.pata.org/survey-reporton-chinese-tourists-travel-intent-after-the-end-of-covid-19-/

Ross, M. (1991). Planning and Heritage: Policy and Practice.London: Spon.

Rypkema, D. D. (2008). Heritage conservation and the local economy. Global Urban Development, 4(1), 1-8.

Samaranayake, H. M. S., Lantra, N., \& Jayawardena, C. (2013). Forty six years of organised tourism in Sri Lanka (1966-2012). Worldwide Hospitality and Tourism Themes, 5(5), 423441.

Samarathunga, WHMS. (2020) 'Post-COVID19 Challenges and Way Forward for Sri Lanka 
Tourism', ResearchGate (Preprints), pp. 1-12. DOI: https://doi.org/10.13140/RG.2.2.32337.89443.

Samarathunga, W. H. M. S. (2019). Research on the intangible ethnic tourism development after a civil war, based on stakeholder perspective: the case of Jaffna, Sri Lanka. International Journal of Tourism Anthropology, 7(3-4), 218-240.

Samarathunga, W. H. M. S., Cheng, L., \&Weerathunga, P. R. (2020). Transitional domestic tourist gaze in a post-war destination: A case study of Jaffna, Sri Lanka. Tourism Management Perspectives, 35, 100693.

Samarathunga, W. and Weerathunga, P. (2020) 'Advent of "Economic Paradigm Shift" and 5G during the Post-COVID19 Revival Phase', MDPI (Preprints), 1, pp. 1-5. DOI: https://doi.org/10.20944/preprints202005.0245.v1.

Saunders, K. (1996). Epochs in Buddhist History. New Delhi: Aryan Books International.

Silva, D., \& Lasanthi, U. (2014). Chinese Inbound Tourism Development in Sri Lanka: Prospects and Challenges, . Colombo: Shaykya Publications.

Sri Lanka Tourism Development Authority (2016). Annual Statistical Report 2015. Colombo: Sri Lanka Tourism Development Authority.

Sri Lanka Tourism Development Authority. (2016). Survey of Departing Foreign Tourists from Sri Lanka. Colombo: Sri Lanka Tourism Development Authority.

Sri Lanka Tourism Promotional Bureau. (2012). Zheng He oration. Retrieved from Sri Lanka Tourism: www.srilanka.travel.

Teo, P., \& Yeoh, B. S. (1997). Remaking local heritage for tourism. Annals of Tourism Research, 24(1), 192-213.

Timothy, D. J., \&Nyaupane, G. P. (2009). Cultural heritage and tourism in the developing world: A regional perspective. London: Routledge.

Torre, M. (2002). Assessing the Values of Cultural Heritage: Research Report. Los Angeles: The Getty Conservation Institute. 
Tse, T. S. (2013). Chinese outbound tourism as a form of diplomacy. Tourism Planning \& Development, 10(2), 149-158. DOI: https://doi.org/10.1080/21568316.2013.783738

United Nations world Tourism Organization. (2019). International Tourism Highlights 2019. https://doi.org/https://www.e-unwto.org/doi/pdf/10.18111/9789284421152

Walsh, K. (1992). The Representation of the Past: Museums and Heritage in the PostModern World. London: Routledge.

Weerasinghe, S. G. M. (1995). A history of the cultural relations between Sri Lanka and China: An aspect of the Silk Route. Central Cultural Fund, Ministry of Cultural Affairs.

Weerathunga, P. and Samarathunga, W. (2020) 'Are We Ready for An Economic Meltdown? The Impact of COVID19 on Sri Lanka Economy', SageAdvance (Preprint). DOI: https://doi.org/10.31124/advance.12230765.v1.

World Tourism Cities Federation. (2014). Market Research Report on Chinese Outbound Tourist (City) Consumption. Ipsos: World Tourism Cities Federation.

World Tourism Organization. (2003). Chinese outbound tourism. Madrid: World Tourism Organization.

World Travel and Tourism Council (WTTC). (2020). Global Economic Impacts and Trends. Retrieved from http://www.wttc.org.

Xinhua News Agency. (2017). Xinhua News Agency. Retrieved from Sri Lanka celebrates visits of Chinese traveler Zheng He: www. China.org.cn.

Yi, X., Lin, V. S., Jin, W., \& Luo, Q. (2017). The Authenticity of Heritage Sites, Tourists' Quest for Existential Authenticity, and Destination Loyalty. Journal of Travel Research, 56(8), 1032-1048.

Zhou, L., King, B., \& Turner, L. (1998). The China outbound market: An evaluation of key constraints and opportunities. Journal of Vacation Marketing, 4(2), 109-119. 